\title{
Long-Term Administration of Calcium Acetate Efficiently Controls Severe Hyperphosphataemia in Haemodialysis Patients
}

\author{
B. Hess ${ }^{1}$ and U. Binswanger ${ }^{2}$ \\ ${ }^{1}$ Medizinische Poliklinik, University of Berne, and ${ }^{2}$ Section of Nephrology, Department of Medicine, University Hospital, \\ Zurich, Switzerland
}

\begin{abstract}
In order to avoid aluminium toxicity, calciumcontaining phosphate binders have been used increasingly. Unfortunately, calcium carbonate and calcium citrate produce hypercalcaemia in a number of patients. New studies have shown that calcium acetate is promising in that it binds more phosphate than calcium carbonate at comparable doses. We tested calcium acetate in eight severely hyperphosphataemic patients $(2.25 \pm 0.08 \mathrm{mmol} / \mathrm{l})$ on maintenance haemodialysis over 5 months. Serum phosphate decreased to $1.86 \pm 0.06 \mathrm{mmol} / \mathrm{l}$, but at the cost of an increase in serum calcium. However, the increment of serum calcium was always less than the respective decrease of serum phosphate, and hypercalcaemia-immediately reversible after dose reduction-only occurred once in two patients.
\end{abstract}

Key words: Phosphate binders; Calcium acetate

\section{Introduction}

Recently, calcium-containing salts such as calcium carbonate [ 1,2$]$ and calcium citrate [3] have been used increasingly as phosphate binders in patients with chronic renal failure. Unfortunately, their long-term administration produces gastrointestinal side-effects and hypercalcaemia in a number of patients $[2,4]$. In addition, citrate enhances gastrointestinal aluminium absorption in patients treated

Correspondence and offprint requests to: Professor Dr U. Binswanger, Section of Nephrology. Department of Medicine, University Hospital, Raemistrasse 100, CH-8091 Zurich, Switzerland. simultaneously with aluminium compounds, thereby increasing the risk of severe aluminium toxicity [5].

Recent investigations have shown that calcium acetate, administered in equivalent doses in a one-meal gastrointestinal balance study to healthy subjects [6] and to haemodialysis patients [7], is equal to aluminium salts, but more efficient than calcium carbonate in its phosphatebinding capacity. This study reports on the long-term effects of calcium acetate in haemodialysis patients with severe hyperphosphataemia.

\section{Patients and Methods}

A newly available calcium acetate preparation (provided by Grosse Apotheke, Dr G. Bichsel, CH-3800 Interlaken, Switzerland) was studied. We selected eight maintenance haemodialysis patients (five men, three women, age 23-64 years) with serum phosphate $>2.0 \mathrm{mmol} / \mathrm{l}$, hypo- or normocalcaemia, and imperfect compliance with recommended dietary guidelines. They had been on thrice-weekly haemodialysis, either $3 \times 3 \mathrm{~h}$ (four cases) or $3 \times 2.5 \mathrm{~h}$ (four cases), for a period of 4-35 months. A Fresenius F-60 dialyser was used, the dialysate was acetate buffered, and dialysate calcium was $1.625 \mathrm{mmol} / \mathrm{l}$.

Previously, four patients had required aluminium hydroxide $(3 \times 400$ or $3 \times 800 \mathrm{mg}$ daily), three were on calcium carbonate $(3 \times 1360 \mathrm{mg}$ calcium carbonate or a total of $1632 \mathrm{mg} \mathrm{Ca}^{2+}$ daily), and one patient was taking aluminium hydroxide $(3 \times 400 \mathrm{mg})$ as well as calcium carbonate $(3 \times 340 \mathrm{mg})$. In all patients previous phosphate binders were replaced by equivalent doses of calcium acetate according to Sheikh et al [6], i.e. a total binder dose of 
Table 1. Serum values before and 1,3 and 5 months after conversion to calcium acetate (CaAc) treatment

\begin{tabular}{|c|c|c|c|c|}
\hline & \multirow{2}{*}{$\begin{array}{l}\text { Before } \\
\text { calcium acetate } \\
(n=7)\end{array}$} & \multicolumn{3}{|c|}{ On calcium acetate treatment for } \\
\hline & & $\begin{array}{l}1 \text { month } \\
(n=7)\end{array}$ & $\begin{array}{l}3 \text { months } \\
(n=6)\end{array}$ & $\begin{array}{l}5 \text { months } \\
(n=6)\end{array}$ \\
\hline $\begin{array}{l}\text { Serum calcium }(\mathrm{mmol} / \mathrm{l}) \\
\text { lonised calcium }(\mathrm{mmol} / \mathrm{l}) \\
\text { Serum phosphate }(\mathrm{mmol} / \mathrm{l}) \\
\text { Ca } \times \mathrm{P}\left(\mathrm{mmol} \mathbf{l}^{2} / \mathrm{l}^{2}\right) \\
\text { Alkaline phosphatase }(\mathrm{IU} / \mathrm{l}) \\
\text { Total protein }(\mathrm{g} / \mathrm{l}) \\
\text { Serum aluminium }(\mu \mathrm{mol} / \mathrm{l})\end{array}$ & $\begin{array}{l}2.26 \pm 0.08 \\
1.19 \pm 0.05 \\
2.25 \pm 0.08 \\
5.03 \pm 0.23 \\
78 \pm 13 \\
71.5 \pm 2.5 \\
0.64 \pm 0.08\end{array}$ & $\begin{array}{l}2.37 \pm 0.08^{4} \\
1.25 \pm 0.05^{2} \\
1.83 \pm 0.12^{3} \\
4.29 \pm 0.23^{2} \\
68 \pm 8 \\
72.0 \pm 2.5 \\
\mathrm{ND}\end{array}$ & $\begin{array}{l}2.37 \pm 0.08^{2} \\
1.26 \pm 0.08^{1} \\
1.84 \pm 0.17^{2} \\
4.27 \pm 0.18^{2} \\
71 \pm 9 \\
71.0 \pm 2.0 \\
\mathrm{ND}\end{array}$ & $\begin{array}{l}2.44 \pm 0.13^{1} \\
1.26 \pm 0.08^{1} \\
1.86 \pm 0.06^{3} \\
4.51 \pm 0.20^{1} \\
72 \pm 6 \\
72.0 \pm 3.0 \\
0.34 \pm 0.07^{1}\end{array}$ \\
\hline
\end{tabular}

Ca $\times P$. serum total calcium $\times$ phosphate product

${ }^{1} P<0.05 ;{ }^{2} P<0.025 ;{ }^{3} P<0.01 ;{ }^{4} P<0.005$ vs value before CaAc treatment; $N D$, not determined

$50 \mathrm{mEq}$ of calcium or aluminium corresponds to $4.33 \mathrm{~g}$ of calcium acetate. Calcium acetate was provided in gelatine capsules $\left(400 \mathrm{mg}\right.$ of calcium acetate or $92.4 \mathrm{mg} \mathrm{Ca}^{2+}$ per capsule) and given in divided doses immediately before and after meals [8]. Informed consent was obtained from all study participants.

Before entering the study and at monthly intervals thereafter, serum total calcium, ionised calcium, phosphate, total protein, urea, creatinine, and alkaline phosphatase were measured. Serum aluminium was determined in all patients at the beginning, and in those previously exposed to aluminium hydroxide at the end of the study. Whenever serum phosphate increased, so did calcium acetate; if hypercalcaemia (total calcium $>2.62 \mathrm{mmol} / \mathrm{l}$ ) occurred, the dose was reduced.

Therapeutic compliance was estimated once weekly by the same physician (BH). Normalised protein catabolic rate [9] was determined monthly. If dietary habits changed, e.g. patients consumed snacks or sandwiches in between regular meals, calcium acetate prescription was adjusted individually.

Serum total calcium, phosphate, total protein, urea, creatinine and alkaline phopsphatase were analysed using standard laboratory techniques. Ionised calcium was measured in whole blood by an ion-selective electrode. Serum aluminium was determined by atomic absorption spectroscopy. All results are expressed as mean \pm SEM. The statistical analysis used Student's $t$ test for paired data.

\section{Results}

Calcium acetate was generally well tolerated. The patients' main complaint was the large number of capsules, $18.4 \pm 1.7$, to be ingested daily; the mean prescribed dose of calcium acetate was $7.36 \pm 0.68 \mathrm{~g} /$ day, or $1693 \pm 156 \mathrm{mg}$ of $\mathrm{Ca}^{2+}$ daily (range $1104-1932 \mathrm{mg} /$ day). No side-effects were noted except diarrhoea in one patient who ended the study prematurely and was not taken into account for further statistical analysis. A second patient finished the protocol after 2.5 months when he received a renal allograft.

Nutritional state did not change during the study, as determined by weight after haemodialysis $(65.8 \pm 3.6 \mathrm{~kg}$ vs $65.3 \pm 4.4 \mathrm{~kg}$ before and at the end of the study, respectively) and by protein catabolic rate $(1.01 \pm 0.09 \mathrm{~g} / \mathrm{kg}$ per day vs $1.15 \pm 0.08 \mathrm{~g} / \mathrm{kg}$ per day).

Table 1 summarises the serum measurements. Mean serum calcium increased significantly, but the increase from baseline at any time during the study was almost always less than the corresponding decrease in serum phosphate (Fig. 1); thus, the calcium $\times$ phosphate product was reduced throughout the whole study period.

Hypercalcaemia of 2.82 and $2.75 \mathrm{mmol} / 1$ respectively, occurred on one occasion in two patients after 2 and 5 months of treatment, respectively, and was reversible after dose reduction. In one patient, reduced calcium acetate intake provoked an increase in serum phosphate from 1.69 to $2.03 \mathrm{mmol} / \mathrm{l}$.

\section{Discussion}

Our main finding is that replacing calcium carbonate or aluminium hydroxyde by equivalent doses of calcium acetate for 5 months improves the control of severe hyperphosphataemia in haemodialysis patients. These results are in accordance with recent short-term studies, where calcium acetate was shown to be equal to aluminium hydroxide but superior to calcium carbonate in its phosphate-binding capacity [6,7]. Given this greater phosphate-binding: calcium-absorption ratio of calcium acetate compared to calcium carbonate, the decrease in serum phosphate to a larger extent than the respective serum calcium increase in almost all our patients (Fig. 1) as well as the low frequency of hypercalcaemia (only one episode in two patients) were to be expected. Similar results have recently been presented [10]. 


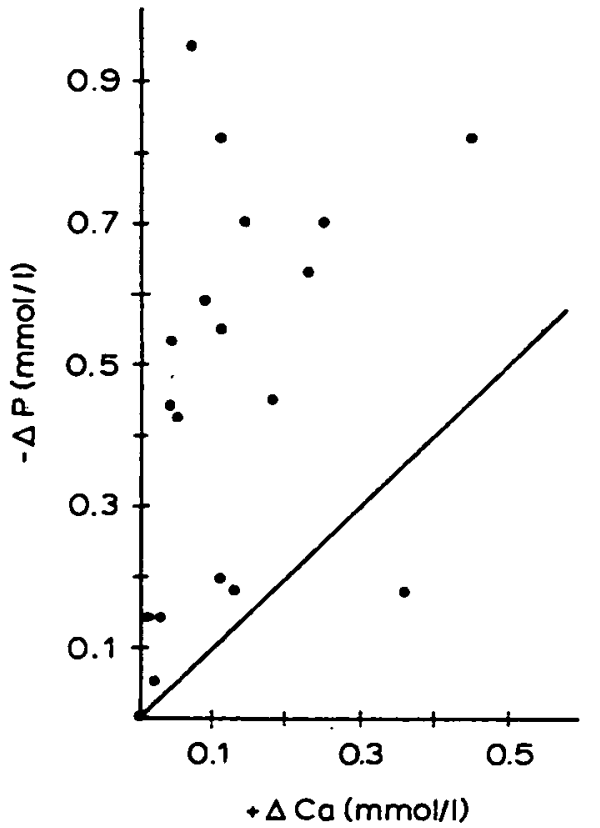

Fig. 1. Correlation between increase of serum calcium $(+\Delta \mathrm{Ca})$ and fall in serum phosphate $(-\Delta \mathrm{P})$. Plot of all individual changes of serum $\mathrm{Ca}$ and $P$ levels from baseline values after 1,3 and 5 months of $\mathrm{CaAc}$ administration. Individual points, with one exception, always lie above the line of identity, indicating that $\mathrm{P}$ decreases to a greater extent than the corresponding increase of $\mathrm{Ca}$.

Our study, however, does not firmly establish the superiority of calcium acetate to calcium carbonate in a long-term regimen, since we did not compare the two compounds in a controlled manner. An average daily dose of $2.5 \mathrm{~g}$ of calcium carbonate, or $1000 \mathrm{mg}$ of $\mathrm{Ca}^{2+} /$ day, clearly below the $1693 \mathrm{mg}$ of $\mathrm{Ca}^{2+} /$ day in this study, was administered for 3 months to considerably less hyperphosphataemic dialysis patients by Williams et al [2]. Nevertheless, average serum calcium increased by $0.14 \mathrm{mmol} / \mathrm{l}$, compared to $0.11 \mathrm{mmol} / \mathrm{l}$ after 3 months in our patients, and calcium $\times$ phosphate products did not decrease [2], as in our study. This might be taken as indirect evidence for the greater treatment efficacy of calcium acetate in a long-term regimen.

In conclusion, treatment with calcium acetate for 5 months is well tolerated and efficient in reducing severe hyperphosphataemia in haemodialysis patients. Controlled trials in a larger group of patients, however, will be needed in order to define whether calcium acetate is superior to calcium carbonate also in a long-term regimen, and whether the general use of calcium acetate might be recommended to all normo- and hypocalcaemic patients with chronic renal failure and hyperphosphataemia.

\section{References}

1. Moriniere P, Hocine C, Boudailliez B et al. Long-term efficacy and safety of oral calcium as compared to $A L(O H)_{3}$ as phosphate binders. Kidney Int 1989; 36 [Suppl 27]: S133-S135

2. Williams B, Vennegoor $M, O$ 'Nunan T, Walls J. The use of calcium carbonate to treat the hyperphosphataemia of chronic renal failure. Nephrol Dial Transplant 1989; 4: 725-729

3. Cushner HM, Copley JB, Lindberg JS, Foulks CJ. Calcium citrate, a nonaluminium-containing phosphate-binding agent for treatment of CRF. Kidney Int 1988; 33: 95-99

4. Coburn JW, Salusky IB. Control of serum phosphorus in uremia (editorial). N Engl J Med 1989; 320: 1140-1141

5. Molitoris BA, Fromet DH, Mackenzie TA, Huffer W, Alfrey AC. Citrate: a major factor in the toxicity of orally administered aluminum compounds (editorial review). Kidney Int 1989; 36: 949-953

6. Sheikh MS, Maguire JA, Emmett $M$ et al. Reduction of dietary phosphorus absorption by phosphorus binders. A theoretical, in vitro, and in vivo study. $J$ Clin Invest 1989; 83: 66-73

7. Mai ML, Emmett M, Sheikh MS, Santa Ana CA, Schiller L, Fordtran JS. Calcium acetate, an effective phosphorus binder in patients with renal failure. Kidney Int 1989; 36: 690-695

8. Schiller LR, Santa Ana CA, Sheikh MS, Emmett M, Fordtran JS Effect of the time of administration of calcium acetate on phosphorus binding. $N$ Engl J Med 1989; 320: 1110-1113

9. Lowrie EG, Teehan BP. Principles of prescribing dialysis therapy: implementing recommendations from the National Cooperative Dialysis Study. Kidney Int 1983; 23 [Suppl 13]: 113-122

10. Emmett M, Sirmon MD, Kirkpatrick WG, Nolan CR, Schmitt GW, Mark VB. Calcium acetate control of serum phosphorus in hemodialysis patients. Kidney Int 1990; 37: 449 (Abstract) 